\title{
Zoological nomenclature - reflections on the recent past and ideas for our future agenda*,
}

\author{
Alessandro Minelli \\ Department of Biology, University of Padova, Via Ugo Bassi 58 B, I 35131 Padova, Italy
}

A couple of weeks after the start of my service as President of the International Commission on Zoological Nomenclature, a paper of mine appeared in the Bulletin of Zoological Nomenclature (Minelli, 1995) in which I outlined some major challenges to be faced by biological nomenclature in response to the changing paradigms of biological systematics. Now, with the approaching end of my six-year term as President, I wish to look in retrospect at the recent history of the Commission, briefly touching on successes and failures alike, and to outline what I now see, from the vantage point of my experience, as further challenges and responsibilities awaiting us; by "us" I mean not merely the Commission but all those active in the field of zoological (or biological) taxonomy.

The main message I will try to convey in this open letter is that a major effort is necessary in order to better integrate the Commission's work into the daily practice of taxonomists world-wide (and also, in a sense, vice versa).

\section{The Commission and the zoological community}

I have come to realise how poorly known amongst zoologists is the activity (or often even the existence) of the Commission. The Code, despite the thousands of copies printed and sold and the translations now available in several languages, is far from being on the shelves of all practising taxonomists. The Bulletin is only present in a rela- tively few libraries, mostly in the richer countries, and is largely ignored as a taxonomist's working tool. As a consequence, the rulings which have been issued by the Commission throughout its history are very often overlooked, despite their obvious relevance and the existence of two most useful volumes that provide an index and summary of them (Melville \& Smith, 1987; Smith, 2001). Questions of nomenclature are sometimes discussed by zoologists, on a personal level, with ICZN members, but this usually happens because the latter are individually known and appreciated within the local, national or taxonomically specialist community as being knowledgeable in these matters, rather than because of their official affiliation with the Commission. Many more queries are addressed to the Commission's Secretariat in London (more numerous indeed than the limited human and material resources available there can readily cope with). Nevertheless, all these questions are just the tip of a huge iceberg of problems of nomenclature floating through the zoological community, sometimes over years and decades without ever being adequately resolved.

Some steps have been taken, however, in order to increase the public awareness of the importance of zoological nomenclature, thus improving the visibility of the Code and the Commission's activity. It is not irrelevant, in my view, that a journal such as Science devoted to the fourth edition of the Code a two-column article in its 7 January 2000 issue (Pennisi, 2000), that is in the very week

*Article reprinted with the permission of the author and the Editor of the Bulletin of Zoological Nomenclature. 
the new Code came into effect. Neither is it irrelevant that an appreciated and widely read monthly such as Trends in Ecology and Evolution hosted my paper on The names of animals in its December 1999 issue (Minelli, 1999). The organizers of the XVIII International Congress of Zoology (Athens, August 2000) selected nomenclature as subject for a General Discussion session that was more than satisfactorily attended. The titles and Abstracts of applications and Commission rulings published in the Bulletin are now displayed on the Commission's Website (www.iczn.org) and so are exposed to a very wide audience.

The time is ripe for "renegotiating" the relationships between the Commission and the zoological community. I am not speaking of constitutional matters, such as ICZN's affiliation with the International Union of Biological Sciences - in this area, I do not see any reason for proposing changes to the current state of affairs - but of the question: how should the problems of nomenclature be addressed in the near future? To better explain my mind, let me deal with new names and old names separately.

Up to now, the Commission has only dealt with new names when writing or updating the relevant provisions in the Code; those rules are then placed in taxonomists' hands and implementation becomes the responsibility of individual workers. Each year thousands of new names thus enter zoological nomenclature through the most diverse bibliographic outlets, some of them exceedingly obscure. A feedback from this activity of taxonomists worldwide will reach the Commission only if, and when, names are found to involve problems which individuals cannot (or do not know how to) solve for themselves. In the meantime, of course, those names have become, in their turn, old names.

Two sets of questions then arise. First, are there any means to improve the way problems with old names are currently addressed by the Commission? Would it be possible to actively involve the whole zoological community in this process? Second, should the Commission take any active role in the "production" of new names? Specifically, should (or could) the Commission be involved in any future system of name registration? My answer to all these questions is yes. I will briefly try to explain why I think so.

\section{Availability of tools}

The Code and the rulings issued by the Commission in response to submitted problems are, or should be, basic tools for all work in zoological taxonomy. For instance, the latest Code is notable in that it allows individuals to take actions to maintain the prevailing usage of names in many circumstances which previously would have needed formal decisions by the Commission.

With the publication of the fourth edition of the Code, some steps have been taken in order to increase its public accessibility. The production of texts in various languages has been strongly encouraged and, for the first time, all of them are equal in authority. At the time of writing the Code is available in English, French, German, Japanese, Russian and Spanish, and Chinese and Ukrainian texts are in an advanced state of preparation; others may follow. There are proposals to produce the Code on $\mathrm{CD}$, supported by adequate searching software, and for a companion or guide which will be easier to understand than the complex wording of the existing Code.

Beyond this, however, I should like to mention two more advanced targets.

The first is a future availability of the Code to any user, free of all cost. The only impediment to the adoption of this policy has been, and still is, the precarious financial position of the Commission. The revenue from the sales of the Code and subscriptions to the Bulletin are, at present, the main source of income which permits the existence of its publications and Secretariat. Technically, it would be easy to have an electronic version of the Code, with searching software, placed on a freely accessible Website. Changes to the financial basis must be made as soon as possible, and indeed might actually happen if the scientific community becomes really aware of the service being offered to it by the Commission and its Secretariat.

My second belief is that in the near future we should try to re-write the Code itself in a much simpler and more user-friendly way than has been traditional. I am not speaking here of changes in what makes a name available or valid, or in the application of the principle of priority (or other 
principles) to homonyms or synonyms; neither of the role and power of the Commission to deal with the relatively rare cases which are controversial or where the Code does not provide a solution. I am speaking instead of the way the rules have been presented in the successive Code editions. The obvious desirability of producing a guide to the Code, or of developing simple and powerful searching tools by which to electronically find the Articles of relevance to a particular problem, means in my view that the current rules could be written in a more straightforward way. The price to pay, of course, would be a break with the traditional layout, but this should not imply a break with established rules of nomenclature. Of course, these rules can be changed, and no doubt some will be, but that is another subject.

Together with the free availability of the Code, I hope we shall be able to offer the zoological community free and easy access to all the Opinions and other rulings issued by the Commission in its 106 years of existence. Digitalization of all relevant documents is currently being considered.

\section{Discussion of cases}

At its meeting held in Athens in August 2000 the Commission discussed at length (see BZN 57: 202 206) procedures which might be adopted in the near future, in order to render the discussion of cases more effective, that is (i) with a larger involvement of the zoological community and (ii) with some degree of decentralization in the management of the discussion, thus obtaining (iii) a substantial reduction in the average time between the submission of the case and the Commission's decision. A small committee has continued working on this subject and the results of this exploration, jointly with the Trust (not-for-profit company) set up in the U.K. to administrate the Commission's financial affairs, will be available shortly. With my Presidential term expiring, I must refrain from promising the adoption of any specific measure. Nevertheless, it is probable that the Commission will quickly move towards a large use of internet facilities for the discussion of cases. Specialist nomenclature committees of international zoological societies and qualified internet discussion groups may be co-opted by the ICZN for handling individual cases, in order to provide a richer and better argued documentation to be forwarded to the Commission for its eventual ruling. Involving more people in the actual discussion of cases may open the way to a larger involvement of the zoological community also in other vital events in the Commission's life, that is in the election of new Commissioners.

\section{Registration of new names}

I should like to come back to the subject of names for newly recognised taxa. The Code Discussion Draft which was widely circulated in 1995 included proposed rules for the registration of all new names. The public discussion elicited by that document demonstrated that the concept of registration was generally acknowledged as valuable, even though some were opposed in principle. However, the further work of the Commission and its Editorial Committee, in the light of the comments provided by many zoologists from different countries, proved that it was not possible to retain those rules in the final text of the fourth edition of the Code because of difficulties in finding an unobjectionable way to implement registration. This is not the place to examine the different options we discussed, or the objections raised to them. What truly matters is to stress that the Commission has never abandoned the hope of making registration into a fact, so that all names become visible rather than being buried in the steadily growing mountain of mostly inaccessible publications. I am firmly convinced of the need for the Commission to be closely involved with any form or mechanism of registration, whatever kind of agency will be eventually responsible for it. Very interesting suggestions for cooperation in this respect have been advanced by the publishers of Zoological Record, an acknowledged primary tool of every active taxonomist.

\section{New taxonomies and nomenclatures}

The Commission cannot (and does not!) quietly sleep in an ivory tower without paying attention 
to deveopments around it, whether actual or suggested, and in the recent literature much has been written of "challenges" to the traditional zoological Code and, equally, to its botanical companion.

When I became ICZN President there was much interest and apprehension about the "BioCode" initiative (see BZN 53: 148-166, September 1996). Several drafts of a unified Code to be eventually adopted for new names of all organisms (bacterial, botanical and zoological) were produced and some lively bursts of discussion developed at international meetings and on the internet. The project was eventually abandoned, mainly owing to manifest difficulties in satisfactorily dealing with already existing names and to unwillingness of many botanists and zoologists alike to part with their traditional rules and to accept registration of new names. For all those who took part in writing or discussing the BioCode drafts, however, this was a useful experience in that it invited a closer study of the long experience underlying the other Codes, and it brought about some minor but useful convergences in the most recent editions of these and to the establishment of a standing International Committee on Bionomenclature to facilitate liaison between the bodies responsible for the Codes (see BZN 58: 6-7).

Things are very different with the "PhyloCode" (see Forey, 2001), not just because this initiative is still being actively pursued by its proponents and is the subject of sustained debate, but because of the basic conceptual issues involved in the contrast between the traditional ("Linnaean") Codes and the proposed PhyloCode. In my 1995 paper, I wrote that "We must expect that the development of cladistics will increasingly ask for a revised biological nomenclature", and this is exactly what is happening with the PhyloCode. To be sure, to be a cladist does not automatically mean to be in favour of the new proposal. For example, this has been strongly criticized by cladists such as Nixon \& Carpenter (2000) and Forey (2001), who do not subscribe to this plea for abandoning Linnaean nomenclature. The next few years will be interesting in this respect.

I like the challenges and the debates, but I cannot conclude otherwise than by repeating the closing words of my 1999 paper, that is: "One can imag- ine that in the future Linnaean and not-Linnaean classification may exist side-by-side. Or maybe not. At any rate, the publication of the new zoological Code could be a good opportunity to open the debate. Otherwise, both parties are likely to go astray: Linnaean-style taxonomists on one side, patiently continuing to produce names that others may be unwilling to use, and phylogenists on the other, perhaps too ready to change the rules. It took one century from Linnaeus to the Strickland Code, and another sixty years to the Règles. Let's talk to one another. Rules can still evolve but a Code, historically, follows and consolidates practice. It does not establish it from scratch."

But the dialogue we need to develop is not just the dialogue between the "phylocoders" and the defenders of Linnaean nomenclature. Starting from a common awareness of the importance of biological systematics, of which nomenclature is a humble but necessary arm, we must all cooperate in developing a common strategy in order to raise, internationally as well as locally, the institutional and financial support that systematic biology fully deserves (Boero, 2001). With a better supported taxonomy, with ICZN's activities much more closely intertwined with taxonomic research than they are at present, and with a much better use of internet facilities, our old Commission should be able to adequately fulfil, well into the new century, its institutional role at the service of zoology.

\section{A personal note}

Let me close on a more personal note. During my six-year term as President there has been a substantial turnover in the Commission's membership. Of the 27 members present at the beginning, 15 (F.M. Bayer, L.R.M. Cocks, J.O. Corliss, G. Hahn, O. Halvorsen, D. Heppell, L.B. Holthuis, Z. Kabata, P.T. Lehtinen, I.W.B. Nye, J.M. Savage, R. Schuster, Y.I. Starobogatov, V.A. Trjapitzin and S.-I. Uéno) retired or left between then and 2000. I wish to thank all of them once more for their valuable contribution to the Commission's work.

In May this year David Ride retired from the Commission after 38 years of service. Twice Presi- 
dent, and editorial Chairman of the third (1985) edition of the Code, David chaired very sensibly and competently the Editorial Committee for the fourth edition. We worked in very close contact between 1996 and 1999, until the new Code was eventually released to the printer. To David I wish to renew the most sincere thanks and appreciation, of the whole Commission and personally mine, for his unique commitment to the Commission and the Code.

I wish also to extend my words of thanks and appreciation to four more people who will retire soon from their very long and productive association with the Commission: in alphabetic order, Harold Cogger, ICZN Vice-President for many years, including the first ones of my term; Claude Dupuis, most perceptive and careful textual critic and wordsmith; Otto Kraus, my energetic predecessor as President; and Philip Tubbs, our knowledgeable and enthusiastic Secretary for 16 years. All were members of the Code Editorial Committee.

I should also like to thank Jeremy Smith and Anthea Gentry, members of the Secretariat, for their long, loyal and invaluable service to the work of the Commission.

The Commission's membership has not just registered losses. Seventeen new members (M.A. Alonso-Zarazaga, W. Böhme, D.J. Brothers, D.R. Calder, W.N. Eschmeyer, N.L. Evenhuis, R.A. Fortey, R.B. Halliday, I.M. Kerzhner, G. Lamas, S.F. Mawatari, P.K.L. Ng, L. Papp, D.J. Patterson, G. Rosenberg, D.X. Song, J. van Tol) have been elected between 1996 and now, representing fourteen different countries, all continents and a wide range of taxonomic fields. Some of them have already had the opportunity of contributing to the Commission's work in a very substantial way. With them, and with the remaining members of the "old guard", is the challenge of placing zoological nomenclature on an increasingly sounder footing, with the active involvement of the whole zoological community.

\section{Acknowledgements}

I am grateful to Bill Eschmeyer and Philip Tubbs for sharing with me their views, not necessarily coinciding with my own, on most of the items mentioned in this article.

\section{References}

Boero, F. 2001. Light after dark: the partnership for enhancing expertise in taxonomy. Trends in Ecology and Evolution, 16: 266 .

Nixon, K.C. \& Carpenter, J.M. 2000. On the other "phylogenetic systematics". Cladistics, 16: 298-318.

Forey, P.L. 2001. The PhyloCode: description and commentary. Bulletin of Zoological Nomenclature, 58: 81-96.

Melville, R.V. \& Smith, J.D.D. (Eds.). 1987. Official Lists and Indexes of names and works in zoology. $306 \mathrm{pp}$.

International Trust for Zoological Nomenclature, London.

Minelli, A. 1995. The changing paradigm of biological systematics: new challenges to the principles and practice of biological nomenclature. Bulletin of Zoological Nomenclature, 52: 303-309.

Minelli, A. 1999. The names of animals. Trends in Ecology and Evolution, 14: 462-463.

Pennísì, E. 2000. Zoology naming rules eased. Science, 287: 26.

Smith, J.D.D. (Ed.). 2001. Official Lists and Indexes of names and works in Zoology. Supplement 1986-2000. 136 pp. International Trust for Zoological Nomenclature, Londờn.

Received: 11 October 2001

\section{Editor-in-Chief's Comment:}

Scientific journals are typically dedicated to publishing original research. However, on occasion something appears in another journal that is of broader interest than just that which is related to that journal. Such is the piece that we have chosen to reproduce here.

Prof. Alessandro Minelli, University of Padua, Italy is retiring as President of the International Commission for Zoological Nomenclature. When nonscientists ask me, "What is this "International Commission"?" I usually answer them that it is the High Court, or the Supreme Court, of zoology. These people usually turn away satisfied, if not more enlightened. However, there are many zoologists who fail to appreciate the work of the Commission, or even know of its existence.

Prof. Minelli's tenure as president has been marked by important changes and milestones. He has supervised the production and publication of the $4^{\text {th }}$ edition of the Code of Zoological Nomenclature. $\mathrm{He}$ also has been a tireless promoter of the work 
of the Commission. As sort of his "farewell address" he published this piece in the Bulletin of Zoological Nomenclature [2001, vol.58(3)]. I believe it admirably sums up not only the work of the Commission, but also its importance to the science of zoology.

The work of the Commission and its associated Secretariat is supported by the International Trust for Zoological Nomenclature. In turn, the trust relies in part on membership contributions of zoologists in either the European or the American Associations of Zoological Nomenclature. We need more of these Associations around the world. However, if you are moved by Prof. Minelli's vision, we would urge you, our readers, to join in supporting the efforts of the Trust.

Frederick R. Schram

Editor-in-Chief 